\title{
In Vitro and FTIR Spectroscopy: Local Black Fruit Seed Extract as Antibacterial Aeromonas Hydrophila
}

\author{
Yori Turu Toja ${ }^{1,4}$, Eddy Suprayitno ${ }^{2}$, Aulanni'am $^{3}$, Uun Yanuhar $^{2}$ \\ ${ }^{1}$ Postgraduate Program, Faculty of Fisheries and Marine Science, University \\ of Brawijaya, Malang, Indonesia \\ ${ }^{2}$ Faculty of Fisheries and Marine Science, University of Brawijaya, Malang, Indonesia \\ ${ }^{3}$ Faculty of Veterinary Medicine, University of Brawijaya, Malang, Indonesia \\ ${ }^{4}$ Faculty of Fishery and Marine Sciences, Indonesia, University of Papua, \\ Manokwari, Indonesia \\ Email: y.toja@unipa.ac.id
}

Received: October 17, 2020. Revised: April 4, 2021. Accepted: April 22, 2021. Published: April 23, 2021.

\begin{abstract}
Indonesia has many local plants with potential as herbal antibacterial properties, one of which is the local black fruit of Wandama. The objective of this study is to determine the antibacterial activity of the extract of black fruit seed against A. Hydrophila by in vitro and FTIR by Tilapia. The benefit of this research is to make black fruit seed extract as a natural remedy against tilapia attacked by Aeromonas Hydrophila. The antibacterial activity of black fruit seed extract against A. Hydrophila is investigated in vitro and using FTIR on tilapia in this research. The aim of this study is to establish black fruit seed extract as a natural treatment for tilapia infected with Aeromonas Hydrophila. The disc approach was used to conduct the in vitro research. Agar medium was poured into a sterile petri dish, and 2 drops of bacteria from the liquid medium were uniformly distributed and cooled. On the press, disc paper with black fruit seed extract was put and incubated for 18-24 hours at 35 C. An FTS 1000 version spectrophotometer system was used for the FTIR test. For the FT-IR study, a fraction of dried black fruit seeds was used. For clear preparation, 100 mg of dry extract is condensed in $\mathrm{KBr}$ pellets. A specimen of loaded black fruit seed samples was analyzed using FTIR spectroscopy with a scanning range of $400-4000 \mathrm{~cm}-1$ and a resolution of $4 \mathrm{~cm}-1$. The results showed that the ethyl acetate fraction produced an inhibition zone $(13.65 \mathrm{~mm})$, the water fraction produced an inhibition zone $(11.21 \mathrm{~mm})$, and the n-hexane fraction produced the weakest inhibition zone $(11.21 \mathrm{~mm})(5.31 \mathrm{~mm})$. The concentration test results from $125 \mathrm{ppm}, 250 \mathrm{ppm}, 500 \mathrm{ppm}$ and $1000 \mathrm{ppm}$ obtained a large inhibition zone at a concentration of $1000 \mathrm{ppm}$ with an inhibition zone area of $11.43+\mathbf{0 . 0 2}$. The absorbance
\end{abstract}

value of black fruit seed extract in ethyl acetate solvent at $3430 \mathrm{~cm}-1$ revealed the absorption band with the strongest vibration of the hydroxylate (-OH) functional group, according to FTIR research. Final thoughts with an average value of $13.65+0.06$, black fruit seed extract using ethyl acetate can inhibit A. Hydrophila bacteria.

Keywords- Black Fruit (Haplolobusmonticola), Wondama, in vitro, FTIR.

\section{INTRODUCTION}

In Indonesia, tilapia is an important freshwater cultivated fish species. The government has set a 2030 deadline for expanding the aquaculture market. Fish is one of the most essential sources of animal protein for a long-term supply. Freshwater fish are a good species for sustainable aquaculture and their potential selection is culturally dependent [1]. The rise in freshwater fish farming is inextricably related to disease outbreaks, which have become roadblocks in the industry because illness has resulted in financial losses and even harvest losses [2], [3].

The rise in freshwater fish farming is inextricably related to disease outbreaks, which have become roadblocks in the industry because illness has resulted in financial losses and even harvest losses. Aeromonas hydrophila, a bacterial disease that commonly affects freshwater fish, has been known in Indonesia since 1980. In 2001, a parasite epidemic affected carp and koi, resulting in widespread mortality in goldfish and koi breeding facilities [4]-[6]. For many years, the global tilapia aquaculture industry has been plagued by disease. In 2014, a new virus known as tilapia lake virus (TiLV) was discovered to be related to the high mortality of tilapia. Aeromonas hydrophila is a potentially pathogenic bacterium in freshwater fish; thus, 
natural ingredients extracted from potentially pathogenic plants are needed to manage A. hydrophila infection. Within vitro studies looking at the zone of inhibition, this research aims to determine which solvent is most useful for use as an antibacterial and determine the antibacterial activity of black fruit seed extract against A. hydrophila.

Indonesia has rich plant biodiversity that can be used to treat a range of ailments. Traditional medicinal plants are unique to each area in Indonesia and are a national cultural heritage that must be protected. Traditional medicine plays a significant role in Indonesian public health services; as a result, it can be created [7]. West Papua is a province rich in indigenous knowledge and plants, including black fruit (Haplolobusmonticola). Because of its economic value, this black fruit has the potential to be grown. Black fruit has been used as a natural preservative in food for decades. The flesh portion of the black fruit is commonly used by the locals because it is mixed with sago and then burned over a pit, increasing the shelf life[8].

Research on black fruit has been conducted by several researchers [9] who have stated that the results of research on black fruit raw leaf extract contain an alkaloid, flavonoid tannins compounds. The tannin content obtained in black fruit leaves ranged from 8.34 percent to 37.26 percent by the Titrimetric Lowenthal-Procter method. [10], [11] suggested the antioxidant potential of black fruit skin and seed extracts. Black fruit skin with ethanol solvent obtained a total phenol content of $8.7102 \mathrm{mg} / 100 \mathrm{gr}$ with $3.8202 \%$ renamed extract. At the same time, Andaman extract used 2.0748 percent hexane with a total phenol content of $6.108 \mathrm{gr} / 100 \mathrm{gr}$. Toja. et al. 2020 found that black fruit seed compounds predicted their interactions with proteins that play a role in peptidoglycan synthesis. Peptidoglycan was selected based on an analysis of the potential of black fruit seeds, which showed higher yields as an inhibitor of Peptidoglycan glycosyltransferase.

The FTIR test can be used to find substances that have the ability to be antibacterial. FTIR spectroscopy is a technique used to qualitatively and quantitatively classify compounds, specifically organic compounds. The shape of the spectrum was examined, and unique peaks suggesting functional groups possessed by a compound were identified [12]. The absorption bands developed during FTIR identification of S. Grandiflora revealed that the $n$-hexane fraction contained flavonoids and terpenoids [13]. Investigating in vitro antioxidants and FTIR analysis of Mannar bay seaweed. It was found that the highest total phenolic content was observed in S. wightii $(0.65 \pm 0.02$ $\mathrm{mg} \mathrm{GAE} / \mathrm{g}$ ) when compared to U. Lactuca. The FITR spectrum of standard gallic acid was compared with seaweed, and the number of similar peaks located between 449.32 and 3495.89 cm-1 and 462.89 and $3407.05 \mathrm{~cm}-1$ was recorded [14].

Various antibiotics, such as ampicillin, tetracyclines, and disinfectants, are often used by fish farmers to avoid disease. Antibiotics are commonly used to treat fish disease. Their use in aquaculture is costly, induces bioaccumulation, and has negative health effects for consumers, such as immunosuppression, residue accumulation in tissues, and the development of drug-resistant pathogens. It also kills fish and pollutes the water. Prevention and treatment, while ensuring biological protection, are the best ways to cope with disease problems. The ethyl acetate extract of black fruit seeds can effectively prevent Aeromonas Hydrophila.

Alkaloids, flavonoids, tannins, polyphenols, triterpenoids, and steroids present in black fruit seeds have been shown to inhibit bacterial growth in phytochemical studies. The local Papuan black fruit seeds are thought to have antioxidant and antibacterial properties, according to these phytochemical studies. There hasn't been any study on black fruit seed extract as a fish medicine until now. As a result, further research is needed to understand the effect of black fruit seed extract on tilapia infected with A. Hydrophila and how it can be used in the fishing industry, especially as an antibacterial agent for tilapia disease. With in vitro studies looking at the zone of inhibition and FTIR, this research aims to determine which solvent is most efficient for use as an antibacterial, as well as the antibacterial activity of black fruit seed extract against A. Hydrophila.

\section{MATERIAL AND METHOD}

\section{Preparation of Black Fruit Seeds (Haplolobus monticola)}

Black fruit seeds were used as a source of material. The sample was prepared before extraction in order to achieve a Simplicia sample. The black fruit is removed from the pulp, cleaned of the skin, and thinly sliced to make smoothing with a blender easier. After cutting, it is dried in a $40 \mathrm{oC}$ oven until the moisture content of the dried black fruit seeds is approximately 12 percent $\mathrm{bb}$, then mashed in a blender to make a powder, which is then sieved using a 40 mesh sieve to obtain black fruit seed powder.

\section{Extraction}

The maceration method was used to remove the samples, with ethyl acetate $(3: 1 \mathrm{w} / \mathrm{v})$ as the solvent. The pulp extract was separated after immersing 50 grams of black fruit seed powder in $200 \mathrm{~mL}$ of ethyl acetate in an Erlenmeyer tube with a screw cap and extracting the pulp extract. Following the completion of the maceration process, the filtrate is collected and concentrated using a rotary vacuum evaporator at a temperature of $40^{\circ} \mathrm{C}$, yielding a thick extract of the black fruit seeds. This procedure takes 48 hours to complete. The more time spent extracting, the more parts are collected. [15].

\section{Fractionation}

Ethyl acetate extract in the form of a paste obtained from maceration, dissolved 5 grams in water solvent, then placed into a separating funnel and partitioned with n-hexane, ethyl acetate with a volume of $75 \mathrm{ml}$ each, partitioned three times (Mogi et al. ., 2016). The funnel is then sealed and vigorously shook to combine the two phases of the solution. After that, the horn is turned over and the tap is opened to let go of the excess vapour pressure. The funnel is then set aside to allow the separation of the two phases to occur. The plug and funnel taps are then opened, and the separating funnel tap is used to isolate the two phases of the solution [16]. The antibacterial activity of the water fraction, $\mathrm{n}$-hexane fraction, and ethyl acetate fraction was then measured at doses of $1000 \mathrm{ppm}, 750 \mathrm{ppm}$, and 500, 250 ppm.

\section{Antibacterial activity test}

The disc approach was used to determine the antibacterial activity of Aeromonas Hydrophila. Prepare a clean petri dish first. Fill the petri dish halfway with ready-made media and set 
aside to cool. Then, using a triangle, uniformly spread two drops of bacteria from the liquid press on the surface of the Petri dish. The disc paper that has been treated with black fruit seed extract (H.monticola) is then placed on the media and gently pressed so that the portion is absorbed after 15-30 minutes. So, there you have it. The press was then incubated for 18-24 hours at $350 \mathrm{C}$. Following inclusion, the presence or absence of a particular site that is formed and measured can be used to observe the inhibition region. To assess the type of H.momticola extract, if it is bacteriostatic or bactericidal, two 24-hour incubations can be performed. If the barrier area remains clear for two 24-hour incubations, it is bacteriocidal; if it is overgrown with bacteria within two 24-hour incubations, it is bacteriostatic.

FTIR Procedure: The FTS 1000 variant spectrophotometer system is used to observe and display specific and functional groups during the analysis process. The Fourier transform infrared spectroscopy (FT-IR) is a technique for identifying the functional groups in a compound. The chemical bonds visible in the annotated spectrum are differentiated by the wavelengths of the absorbed light. Using the chemical bonds in an undetermined molecule, the infrared absorption spectrum can be estimated. For FT-IR analysis, we used dried black fruit seed fraction. For a transparent preparation, $100 \mathrm{mg}$ of dry extract is compressed into $\mathrm{KBr}$ pellets. A specimen of loaded black fruit seed samples was scanned with a scanning range of 400-4000 $\mathrm{cm}-1$ and a resolution of $4 \mathrm{~cm}-1$ using FT-IR spectroscopy.

\section{RESULTS AND DISCUSSION}

Disc Method: The use of The wondama local black fruit seed extract here is thought to be novel since they have not been use previously fo used as a natural antibacterial in the prevention of Aeromonas Hydrophila disease.This section illustrates the results of our procedure. The antibacterial activity of the active compounds of black fruit seeds was tested in vitro using disk paper. The inhibitory test uses several solvents as a comparison to find the best solution for the most significant inhibition, including the water fraction, the n-hexane fraction, and the ethyl acetate fraction. Besides, the inhibitory test was performed using the best fraction previously tested with different concentrations, including $15.63 \mathrm{ppm}, 31.25 \mathrm{ppm}, 62.5 \mathrm{ppm}, 125$ ppm, $250 \mathrm{ppm}, 500 \mathrm{ppm}, 750 \mathrm{ppm}$, and $1000 \mathrm{ppm}$, so that the best concentration value can be found to be applied to the in vivo test at a later stage. The results of the two types of tests are presented in Table 1. and Table 2.

The best fraction that produces a larger inhibition zone is ethyl acetate with an average value of $13.65+0.06$, based on Table 1. On the other hand, the water fraction gives an inhibition zone with an average value of $11.21+0.09$. The $n-$ hexane fraction is the weakest, with an average inhibition zone of $5.31+0.04$. Based on these results, ethyl acetate was chosen as the fraction to be used in the next in a vitro test phase.

Table 2 shows the results of the best concentration test used in this study, where the inhibitory power activity began to appear at a concentration of $125 \mathrm{ppm}$ with an average value of $5.16+0.15$ and continued to show an increase in the inhibition zone along with an increase in the concentration tested, with an average inhibition zone of $9.25+0.25 \mathrm{ppm}$ at a concentration of $250 \mathrm{ppm}$. The highest concentration used in this study is 1000 ppm, which is shown to be inhibitory with an average area of $11.43+0.02$.

The results obtained are then concluded with a comparison of the inhibitory capacity of the active compound against the bacterial activity. The inhibition zone formed after the incubation period is measured and recorded[17]. [18]classified the criteria for bacterial inhibition by suggesting that the inhibition zone diameter of $0 \mathrm{~mm}$ does not inhibit, $5-10 \mathrm{~mm}$ is weak, $11-20 \mathrm{~mm}$ is strong, $>22 \mathrm{~mm}$ is very strong.

The above classification shows that the inhibitory ability of black fruit seed extract against A. hydrophila bacteria at the highest concentration, i.e. $1000 \mathrm{ppm}$, shows intense activity. This is also supported by several opinions of [19], which state that the bacterial inhibitory response $\leq 5 \mathrm{~mm} 6-10 \mathrm{~mm}$ is weak, $11-20 \mathrm{~mm}$ is strong $\geq 21 \mathrm{~mm}$ is very strong. [20] classified the four reactions as $<5 \mathrm{~mm}$ weak, $5-10 \mathrm{~mm}$ moderate, $10-19 \mathrm{~mm}$ strong, $>20 \mathrm{~mm}$ very strong. With an inhibitory ability that continues to increase with increasing concentrations used, the raw extract of black fruit seeds may be a candidate for use at the next stage of the research, namely in vivo.

Minimum Inhibitory Concentration (MIC) Test Results: The Minimum Inhibitory Concentration (MIC) test was used to assess the lowest dose of ethyl acetate extract of black fruit seeds that were effective in destroying A. hydrophila bacteria. Using a spectrophotometer, the MIC test was observed by looking at the Optical Density, which is determined by the turbidity level of the liquid media. This test employs a variety of doses, ranging from $15.63 \mathrm{ppm}$ to $1000 \mathrm{ppm}$, as well as positive $(+)$ and negative (-) control tests. The following are the results of the MIC exam, as shown in Table 3.

According to the table above, the black fruit seed extract will inhibit the growth of A. hydrophila bacteria, with a decrease in the OD value with each increase in the number of doses measured, indicating a decrease in bacterial growth. The OD value is decreasing, indicating that the test media is becoming clearer and the spectrophotometer is absorbing fewer particles. Bacterial cells that grow on the test media make up the particles. However, at a dose of $500 \mathrm{ppm}$, the OD value started to drop dramatically, to 0.061 and continued to fall at a dose of $750 \mathrm{ppm}$, to 0.059 , and a dose of $1000 \mathrm{ppm}$, to 0.035 . This indicates that the antibacterial activity of black fruit seed extract will destroy A. hydrophila bacteria at a MIC dose of 500 ppm, while a dose less than 500 ppm can only inhibit A. hydrophila bacteria development.

The flavonoid compounds found in black fruit can inhibit the growth of bacteria by interfering with the permeability of the bacteria's cell walls. Flavonoids have antibacterial properties because flavonoids as derivatives of phenols can cause damage to the structure and change the bacterial cell wall's permeability mechanism. Besides, the flavonoid is a flavonol group, so that it has chemical properties of phenol compounds. The mechanism of action of flavonoids as antimicrobials can be divided into 3 , namely inhibiting nucleic acid synthesis, inhibiting cell membrane function and inhibiting energy metabolism (Hendra et al., 2011). Damage to bacterial cell walls, changes in cell permeability, damage to bacterial nucleic acids, changes in protein molecules, and inhibition of nucleic acid synthesis processes can all prevent bacteria from reproducing. As A. hydrophila infects the host by releasing an 
enzyme that can break down the host's blood cells, the function of enzymes released by bacterial cells is inhibited [21], [22].

Bacterial cells are encased in a peptidoglycan cell wall, which is made up of a long sugar polymer. The peptidoglycan uses trans glycosidase to crosslink the glycan chains, and the peptide chain extends from the polymer's sugar and forms cross-links between peptides. Bacteria are classified into two groups based on their chemical composition: gram-positive bacteria and gram-negative bacteria [23]-[25]. cytoplasmic membrane is bound by a rigid and durable tissue called the cell wall in Gram-positive bacteria. Gram-negative bacteria, on the other hand, have a thin cell wall surrounded by a second lipid membrane known as the outer membrane (OM). OM is an extra layer of protection on gram-negative bacteria that prevents various substances from entering the cells. This membrane, however, contains porins, which enable molecules from outside the cell, such as drugs, to reach the cell [26].

In general, antibacterials work by damaging bacterial cell walls, which is the first step to inhibiting bacterial growth. The cell wall itself is the earliest defense possessed by bacteria; if the cell wall is damaged, the antibacterial compounds will more easily enter the cell and interfere with the cell organelles' function in it. The active compounds contained in black fruit seed extracts such as flavonoids, polyphenols, alkaloids, and terpenoids can damage the bacterial cell membrane by changing the phospholipids that make up the cell membrane into other forms such as phosphoric acid, carboxylic acid, and glycerol which cause changes in the shape of the cell membrane or the cell is unable to maintain its shape and maintain the organelle that will work in the process of bacterial cell growth so that in the end the bacterial cell becomes lysis and experiences death [27], [28]. One of the processes of the growth inhibition of A. hydrophila bacteria is by inhibiting its enzyme activity because these bacteria work to infect targets by transferring enzymes that can enter the blood cells, causing infection in the host.

The active compounds in Black Fruit Seed Extract were identified and characterized using Fourier Transform Infrared (FTIR): Fourier Transform Infrared (FTIR) Spectrophotometry can be used to determine the functional groups of a chemical compound. This test is needed to ensure that the chemical compounds in the black fruit seed extract $(\mathrm{H}$. monticola) can be identified using the absorption expression of a specific wavelength number. The following are the FTIR test results of black fruit seed extract (H. monticola) with ethyl acetate solution, as shown in Figure 2.

The graph of the absorbance value of black fruit seed extract with ethyl acetate solvent at a wavelength of $3430 \mathrm{~cm}-1$ shows the absorption band with the most detailed shape, which shows the strongest vibration of the hydroxylate $(-\mathrm{OH})$ functional group. At absorbance wavelengths of 1707-1619 cm1 , the vibrations of the carboxylic acid functional group $(\mathrm{C}=\mathrm{C})$ are noticeable, while $1384 \mathrm{~cm}-1$ indicates the presence of a methyl functional group (-CH3) and $1344 \mathrm{~cm}-1$ indicates the functional group of the compound. Aromatic nitro (-C-NO2) indicates the presence of an alcohol functional group (CO) at a wavelength of 1213-1037 cm-1, an aromatic alkene functional group $(\mathrm{CH})$ at a wavelength of 764-689 cm-1, and monobranched alkane functional group vibrations at a wavelength of $604-518 \mathrm{~cm}-1$ (-CH3). The results of FTIR identification of the chemical compounds of black fruit seed extract contained in it are hydroxylates, carboxylic acids, methyls, aromatic nitrogen, alcohols, aromatic alkenes, monobranch alkanes.

\section{CONCLUSION}

These findings support the conclusion that the black fruit seed herbal extract tested was proven to inhibit the growth of A. Hydrophila in vitro. Of the three solvent fractions used, ethyl acetate produced a more significant inhibition zone with an average inhibition zone value of $13.65+0.06$. Test the concentration of $125 \mathrm{ppm}, 250 \mathrm{ppm}, 500 \mathrm{ppm}$, and $1000 \mathrm{ppm}$ obtained a large inhibition zone at a concentration of $1000 \mathrm{ppm}$ with an inhibition zone area of $11.43+0.02$. The results of FTIR identification of the chemical compounds of black fruit seed extract contained in it are hydroxylates, carboxylic acids, methyls, aromatic nitrogen, alcohols, aromatic alkenes, monobranch alkanes.

\section{AUTHOR'S CONTRIBUTION}

YTT designed the research and wrote the manuscript., ES AA and UY reviewed the manuscript.

\section{ACKNOWLEDGMENT}

I am thankful for the scholarship and the financial support from to the Ministry of Research, Technology and Higher Education of the Republic of Indonesia (Kemenristekdikti), Raja Ampat Regency Government for financial support, Wondama Community for assistance in the field, Disease Laboratory of the Faculty of Fisheries and Marine Sciences, Brawijaya University. Finally, we are very grateful.

\section{References}

[1] G. Yue, H. Lin, and J. Li, "Tilapia is the fish for nextgeneration aquaculture," Int J Marine Sci Ocean Technol, vol. 3, no. 1, pp. 11-13, 2016.

[2] K. Thanikachalam, M. Kasi, and X. Rathinam, "Effect of garlic peel on growth, hematological parameters and disease resistance against Aeromonas Hydrophila in African catfish Clarias gariepinus (Bloch) fingerlings," Asian Pacific Journal of Tropical Medicine, vol. 3, no. 8, pp. 614-618, 2010.

[3] S. S. Giri, V. Sukumaran, and M. Oviya, "Potential probiotic Lactobacillus plantarum VSG3 improves the growth, immunity, and disease resistance of tropical freshwater fish, Labeo rohita," Fish \& shellfish immunology, vol. 34, no. 2, pp. 660-666, 2013.

[4] I. Lukistyowati and K. Kurniasih, "Kelangsungan Hidup Ikan Mas (Cyprinus carpio L) yang Diberi Pakan Ekstrak Bawang Putih (Allium sativum) dan di Infeksi Aeromonas Hydrophila," Jurnal perikanan dan kelautan, vol. 16, no. 02, pp. 144-160, 2011.

[5] I. Lukistyowati, "Pelacakan Gen Aerolysin dari Aeromonas Hydrophila pada Ikan Mas yang Diberi Pakan Ekstrak Bawang Putih (Detection Of Aerolysin Gen From Aeromonas Hydrophila In Common Carp Fed 
With Garlic Extract)," Jurnal Veteriner, vol. 13, no. 1, pp. 43-50, 2012.

[6] Y. Mulyani, E. Bachtiar, and M. U. K. Agung, "Peranan senyawa metabolit sekunder tumbuhan mangrove terhadap infeksi bakteri Aeromonas Hydrophila pada ikan Mas (Cyprinus carpio L.)," Jurnal Akuatika, vol. 4, no. 1, 2013.

[7] R. Dewantari, M. Lintang, and N. Nurmiyati, "Jenis Tumbuhan yang Digunakan sebagai Obat Tradisional Di Daerah Eks-Karesidenan Surakarta," Bioedukasi: Jurnal Pendidikan Biologi, vol. 11, no. 2, pp. 118-123, 2018.

[8] E. Sirami, "Pohon Buah Hitam (Haplolobus spp.) Keistimewaannya Bagi Masyarakat Kabupaten Teluk Wondama," Warta Konservasi Lahan Basah, vol. 18, no. 2, pp. 1-7, 2010.

[9] L. A. Rahman and E. Somar, "Ekstrak tannin daun buah hitam (haplolobus sp) sebagai inhibitor alami korosi besi dalam larutan asam," Jurnal Natural, vol. 16, no. 1, pp. 61-65, 2020.

[10] E. L. Floren, "Ekstraksi dan pengujian biji buah hitam (haplolobus floribunda hj lam) sebagai sumber antioksidan alami," 2013.

[11] S. Rumkorem, "Pengujian Kapasitas Antioksidan Kulit Buah Hitam (Haplolobus floribunda HJ Lam) Asal Kabupaten Teluk Wondama Papua Barat," 2013.

[12] C. Y. Ragasa, P. Tsai, and C.-C. Shen, "Terpenoids and sterols from the endemic and endangered Philippine trees, Ficus pseudopalma and Ficus ulmifolia," Philipp $J$ Sci, vol. 138, no. 2, pp. 205-209, 2009.

[13] S. Ndahawali, S. Andayani, and H. Hardoko, "Phytochemical Screening by FTIR Spectroscopic Analysis and Antibacterial Activity of Sesbania grandiflora," The Journal of Experimental Life Science, vol. 9, no. 3, pp. 176-180, 2019.

[14] S. Meenakshi, S. Umayaparvathi, M. Arumugam, and T. Balasubramanian, "In vitro antioxidant properties and FTIR analysis of two seaweeds of Gulf of Mannar," Asian Pacific Journal of Tropical Biomedicine, vol. 1, no. 1, pp. S66-S70, 2011.

[15] O. M. Prameswari and S. B. Widjanarko, "Uji Efek Ekstrak Air Daun Pandan Wangi Terhadap Penurunan Kadar Glukosa Darah Dan Histopatologi Tikus Diabetes Mellitus [In Press 2014]," Jurnal Pangan dan agroindustri, vol. 2, no. 2, pp. 16-27, 2013.

[16] L. Darlian, "Skrining Bioaktivitas Ekstrak Kulit Akar Bakau Merah (Rhizophora apiculata bl.) Terhadap Daya Hambat Pertumbuhan Koloni Bakteri Streptococcus sp.," Jurnal Progres Kimia Sains, vol. 1, no. 2.

[17] R. A. Islamy, U. Yanuhar, and A. M. S. Hertika, "Assessing the Genotoxic Potentials of Methomyl-based Pesticide in Tilapia (Oreochromis niloticus) Using Micronucleus Assay," The Journal of Experimental Life Science, vol. 7, no. 2, pp. 88-93, 2017.

[18] W. Davis and T. Stout, "Disc plate method of microbiological antibiotic assay: I. Factors influencing variability and error," Applied microbiology, vol. 22, no. 4, pp. 659-665, 1971.

[19] D. S. Susanto and R. Ruga, "Studi kandungan bahan aktif tumbuhan meranti merah (Shorea leprosula Miq) sebagai sumber senyawa antibakteri," Mulawarmnan Scientifie, vol. 11, no. 2, pp. 181-190, 2012.

[20] U. Suriawiria, "Mikrobiologi dasar," Jakarta: Papas Sinar Sinanti, p. 172, 2005.

[21] K. R. Sumayani and Y. Cahyoko, "Daya antibakteri perasan rimpang lengkuas (Alpinia galanga) dengan konsentrasi berbeda terhadap pertumbuhan Aeromonas Hydrophila Secara in vitro," Berkala Ilmiah Perikanan, vol. 3, no. 1, pp. 83-87, 2008.

[22] N. Gobi et al., "Dietary supplementation of probiotic Bacillus licheniformis Dahb1 improves growth performance, mucus and serum immune parameters, antioxidant enzyme activity as well as resistance against Aeromonas Hydrophila in tilapia Oreochromis mossambicus," Fish \& shellfish immunology, vol. 74, pp. 501-508, 2018.

[23] X. Li et al., "Efficiency of chemical versus mechanical disruption methods of DNA extraction for the identification of oral Gram-positive and Gram-negative bacteria," Journal of International Medical Research, vol. 48, no. 5, p. $0300060520925594,2020$.

[24] T. D. Tavares et al., "Activity of specialized biomolecules against Gram-positive and Gram-negative bacteria," Antibiotics, vol. 9, no. 6, p. 314, 2020.

[25] K. Prasad et al., "Synergic bactericidal effects of reduced graphene oxide and silver nanoparticles against Grampositive and Gram-negative bacteria," Scientific reports, vol. 7, no. 1, pp. 1-11, 2017.

[26] W. C. Reygaert, "An overview of the antimicrobial resistance mechanisms of bacteria," AIMS microbiology, vol. 4, no. 3, p. 482, 2018.

[27] S. Kırmusaoğlu, Antimicrobials, Antibiotic Resistance, Antibiofilm Strategies and Activity Methods. BoD-Books on Demand, 2019.

[28] M. Pelczar and E. Chan, "Dasar-dasar Mikrobiologi 1 dan 2," Penerjemah Ratna. SH Penerbit Universitas Indonesia: Jakarta, 2005.

Creative Commons Attribution License 4.0 (Attribution 4.0 International, ,CM3 BY 4.0)

This article is published under the terms of the Creative Commons Attribution License 4.0

https://creativecommons.org/licenses/by/4.0/deed.en_US 
Table 1. Inhibitory Test Results of Various Black Fruit Seed (H. monticola) Fractions

\begin{tabular}{lcccc}
\hline Fraction & \multicolumn{3}{c}{ Inhibition Zone (mm) } \\
\cline { 2 - 4 } & \multicolumn{3}{c}{ Repetition } & Mean \pm SD \\
\cline { 2 - 4 } Water & 11.29 & 2 & 3 & $11.21 \pm 0.09$ \\
N-hexane & 5.36 & 11.12 & 11.22 & $5.31 \pm 0.04$ \\
Ethyl Acetate & 13.40 & 13.29 & 5.29 & $13.65 \pm 0.06$ \\
\hline
\end{tabular}

Table 2. The Result of Inhibitory Test of Ethyl Acetate Fraction of Black Fruit Seeds (H. monticola)

\begin{tabular}{|c|c|c|c|c|c|}
\hline \multirow[t]{3}{*}{ Concentration (ppm) } & \multicolumn{5}{|c|}{ Inhibition Zone (mm) } \\
\hline & \multicolumn{3}{|c|}{ Repetition } & & \multirow[t]{2}{*}{ Mean \pm SD } \\
\hline & 1 & 2 & 3 & & \\
\hline 1000 & 11.45 & 11.42 & 11.41 & & $11.43 \pm 0.02$ \\
\hline 750 & 11.16 & 11.29 & 11.22 & & $11.22 \pm 0.06$ \\
\hline 500 & 10.31 & 10.22 & 10.4 & & $10.31 \pm 0.09$ \\
\hline 250 & 9.19 & 9.31 & 9.24 & & $9.25 \pm 0.06$ \\
\hline 125 & 5.17 & 5.31 & 5.02 & & $5.16 \pm 0.15$ \\
\hline 62.5 & - & - & - & & - \\
\hline 31.25 & - & - & - & & - \\
\hline 15.63 & - & - & - & - & \\
\hline
\end{tabular}

Table 3. Results of the Minimmune Inhibitory Concentration (MIC) test of ethyl acetate extract of black fruit seeds (H. monticola) against A. hydrophila

\begin{tabular}{lc}
\hline Concentration $(\mathbf{p p m})$ & Od value \\
\hline $\mathbf{K}+$ & 0.001 \\
$\mathbf{K}-$ & 0.275 \\
$\mathbf{1 0 0 0}$ & 0.035 \\
$\mathbf{7 5 0}$ & 0.059 \\
$\mathbf{5 0 0}$ & 0.061 \\
$\mathbf{2 5 0}$ & 0.104 \\
$\mathbf{1 2 5}$ & 0.120 \\
$\mathbf{6 2 . 5}$ & 0.148 \\
$\mathbf{3 1 . 2 5}$ & 0.167 \\
$\mathbf{1 5 . 6 3}$ & 0.181 \\
\hline
\end{tabular}




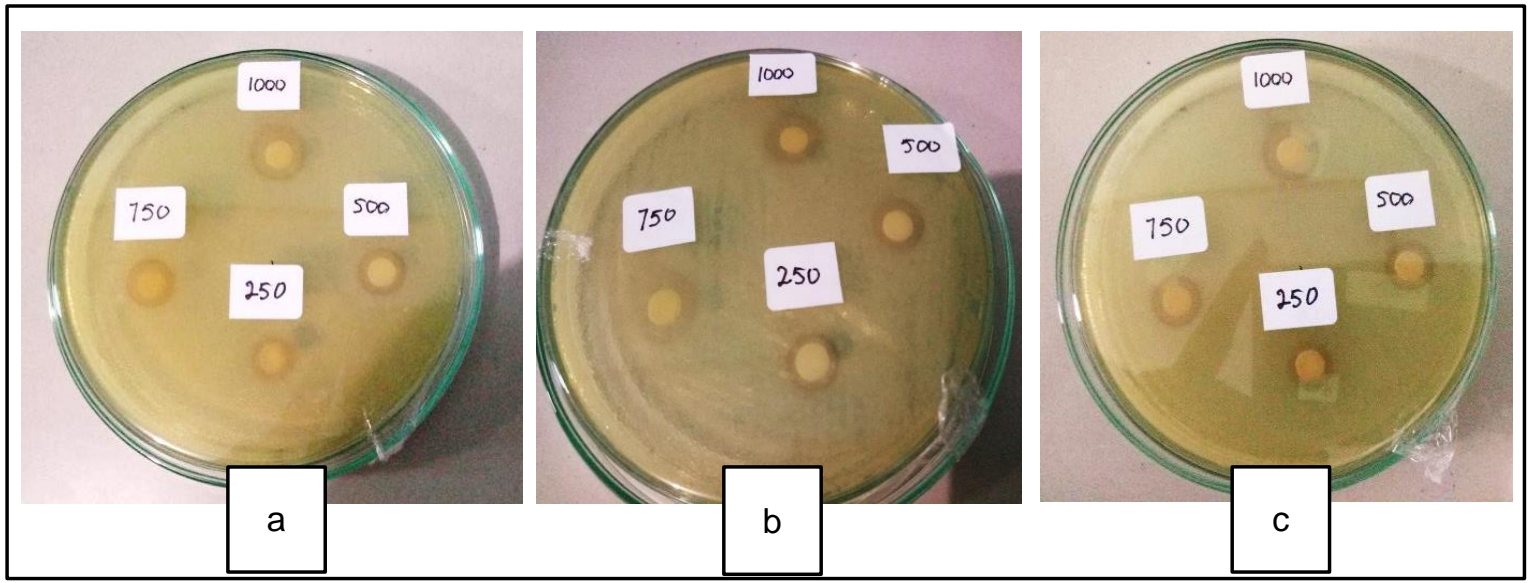

Figure 1. Inhibitory test of black fruit seed (H. monticola) extracts at doses of $250 \mathrm{ppm}, 500 \mathrm{ppm}, 750 \mathrm{ppm}$, and $1000 \mathrm{ppm}$. a) The inhibitory test of repetition 1, b) The inhibitory test of repetition 2, c) The inhibitory test of repetition 3

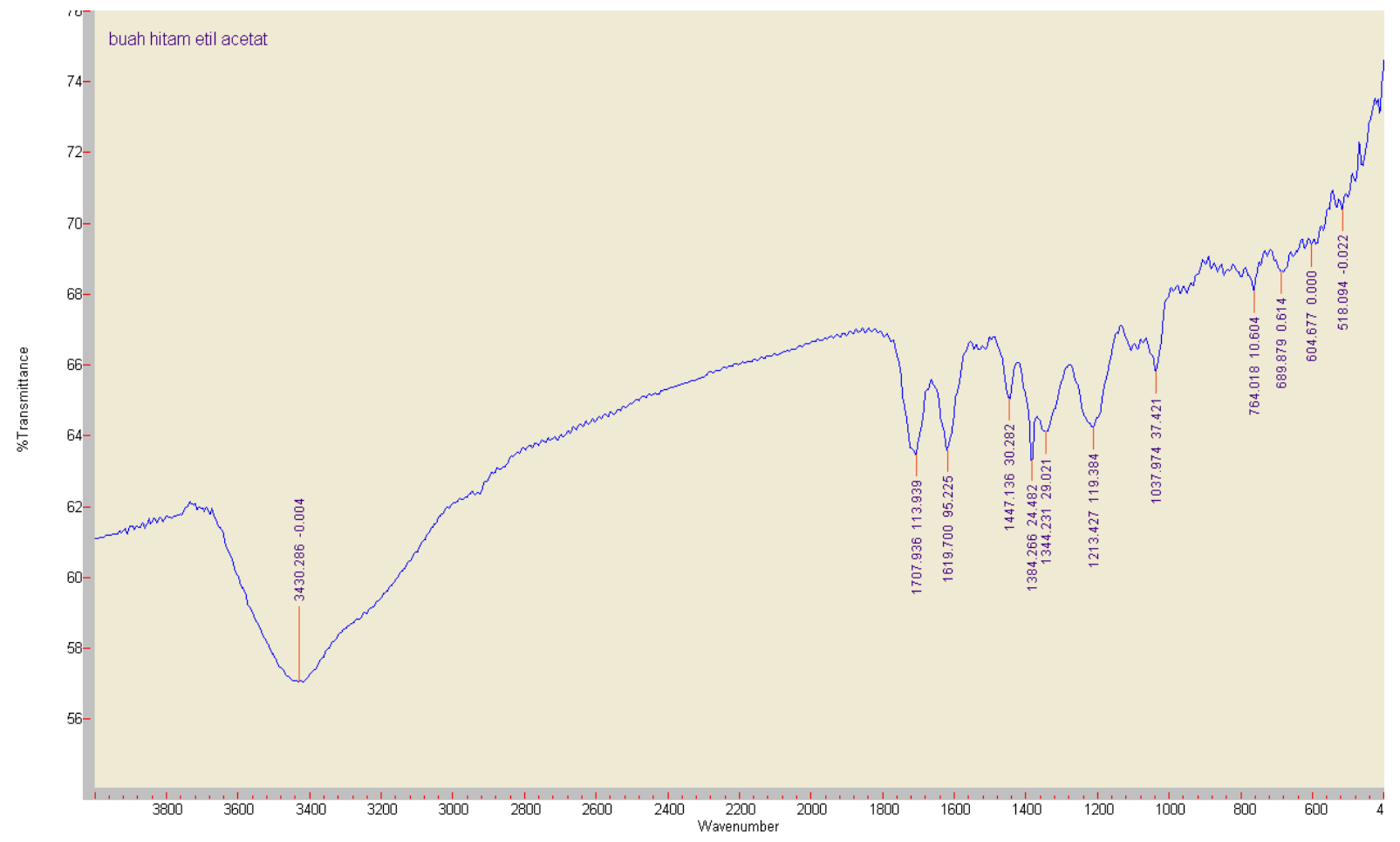

Figure 2. Infrared Wavelength Spectrum of Ethyl Acetate Extract of Black Fruit Seeds (H. monticola) $4000-500 \mathrm{~cm}-1$ 